\title{
POSSIBILITIES OF DYNAMIZATION OF CULTURAL TOURISM PRODUCTS
}

\author{
[Možnosti dynamizace produktů kulturního cestovního ruchu] \\ Alena Zedková ${ }^{1}$ \\ ${ }^{1}$ Slezská univerzita, Obchodně podnikatelská fakulta, Univerzitní nám. 1934/3, 73340 Karviná \\ Email:alena.zedkova@seznam.cz
}

\begin{abstract}
The paper deals with the issue of cultural tourism products with focus on organized events, which are considered as important factors dynamizing the tourism supply. Organized events can be sufficient motive to travel, or they can be secondarily leisure activities in the visited destination, when the main motive of journey is different. The contribution, in its analytical part, introduces the supply and demand for cultural events in the Czech Republic, but attention is given mainly to two selected regions, Moravian-Silesian Region and Olomouc Region. Aim of this contribution is to highlight the importance of cultural events in tourism of the Czech Republic, especially in the selected regions.
\end{abstract}

Keywords: cultural destination, cultural tourism, event, Moravian-Silesian Region, Olomouc Region, tourism product.

JEL classification: L83

Doručeno redakci: 13.5.2016; Recenzováno: 27.5.2016; 30.5.2016; Schváleno k publikování: 19.10.2016

\section{Úvod}

Produkt kulturního cestovního ruchu je základem nabídky kulturních destinací. Úspěšný produkt kulturní destinace musí být natolik přitažlivý, že vyvolá zájem zákazníků, turistů, návštěvníků. Ona přitažlivost je dána jednak kvalitním tzv. jádrem produktu, jež zajistí uspokojení potřeby účastníka cestovního ruchu (potřeba poznávání a vzdělávání se může být uspokojena např. návštěvou památkového objektu, atraktivní lokality, inscenované události apod.), a jednak kvalitními doprovodnými službami, tzn. rozšířeným produktem. V České republice je každoročně pořádána řada nejrůznějších kulturních akcí, resp. akcí, které mají dopad i do oblasti kulturního cestovního ruchu. Tzn., jedná se o takové akce, které kromě jiného umožňují poznávat kulturu a tradice navštívené destinace, př́íp. rozšiřují nabídku tzv. kulturního vyžití v oblasti.

Cílem př́spěvku je poukázat na význam kulturních událostí jako nástroje dynamizace nabídky cestovního ruchu. S využitím statistických údajů ČSÚ a NIPOSu (Národního a poradenského střediska pro kulturu) bude provedena analýza a komparace počtu jednotlivých kulturních destinací České republiky a jejich návštěvnosti se zaměřením zejm. na kulturní události dvou vybraných regionů, a sice Moravskoslezského a Olomouckého kraje. Prostřednictvím korelační analýzy budou ověřeny hypotézy o existenci statistické závislosti mezi počtem kulturních událostí v těchto krajích a počtem jejich návštěvníků.

Ačkoliv v současnosti jsou využívány právě organizované kulturní akce jako prostředek obohacení nabídky cestovního ruchu, které právě tuto nabídku dynamizují, nevyužívají všechny kraje této možnosti rozvoje cestovního ruchu v dostatečné míře.

\section{Kulturní cestovní ruch a kulturní destinace}

Kultura a kulturní důvody výrazně motivují lidstvo k cestování. Kulturní turisty vede touha po prožití něčeho výjimečného, možnost poznávat nové kraje a jejich obyvatelstvo, způsob jejich 
života, stejně tak poznat i umění, historii a kulturu. Turisté při svých cestách tedy projevují jakousi potřebu seberealizace. Spojení cestování a poznávání kultury a všech jejích aspektů reprezentuje jedna z forem cestovního ruchu, a to kulturní cestovní ruch.

\subsection{Kulturní cestovní ruch}

Kulturní cestovní ruch resp. kulturně poznávací cestovní ruch je jednou z forem cestovního ruchu, která zahrnuje širokou škálu motivů k jeho realizaci. Může se jednat o poznávání historie, zvyků a tradic, kultury a uskutečňuje se formou návštěvy kulturně historických památek (hradů, zámků, staveb lidové architektury apod.) a dalších kulturních objektů (galerie, muzea, knihovny). Dále sem můžeme zahrnout i účast na různých kulturních událostech (festivaly, koncerty, divadelní představení, folklorní akce), ale např. i návštěvu tzv. kulturní krajiny (zahrady, parky), či návštěvu zoologických a botanických zahrad, které Johnová (2008, s. 33) považuje za specifický typ muzeí. Kulturní cestovní ruch plní výchovně vzdělávací funkci a přispívá k rozšíření kulturně společenského rozhledu (Indrová 2007, s. 18).

Podle Světové organizace cestovního ruchu, UNWTO (In Kesner a kol. 2008, s. 9) je kulturní cestovní ruch definován jako pohyb osob především z kulturních důvodů, jako jsou studijní cesta, umělecké představení, kulturní zájezd, cestování na festival a další akce, návštěva památek a sídel, cesta za poznáváním př́rody, folklórem, uměním či poutěmi. UNWTO (2001, s. 100) dále uvádí, že kulturní cestovní ruch zahrnuje kulturní aktivity a zážitky, které přitahují návštěvníky a zvyšují návštěvnost destinací. Kulturní cestovní ruch je o radosti z poznávání životního stylu místních obyvatel, poznávání navštívené oblasti a toho, co jí dává identitu a charakteristické vlastnosti.

Kulturním cestovním ruchem návštěvníci uspokojují své duševní a duchovní potřeby potřebu poznávání, vzdělávání se, účasti na náboženských obřadech. Návštěvami kulturně historických památek a kulturních událostí poznávají kulturu a historii určitého společenství lidí. Kulturní cestovní ruch lze považovat za hlavní nositel kulturní výměny a zachování dědictví (Kmeco 2006, s. 5).

\subsection{Kulturní destinace}

V tom nejobecnějším pojetí můžeme destinaci cestovního ruchu definovat jako určitý geografický prostor (stát, region, město, místo), který si účastník cestovního ruchu vybírá jako cíl své cesty (Jakubíková 2012, s. 37).

Kulturní destinace je však taková destinace, která je cílem kulturní turistiky a v jejíž nabídce se výrazně či dominantně uplatňuje kultura. Může se jednat jak o jednotlivá zařízení (muzea, galerie, historické památky, skanzeny či konkrétní výstavy), tak o celé regiony, města a obce, na jejichž území se nacházejí atraktivní a navštěvované historické památky, muzea, kulturní krajina a jiné kulturní atraktivity a akce (Kesner a kol. 2008, s. 54). Za kulturní destinace a významné kulturní zdroje pak Kesner (2005, s. 18 - 30) považuje kulturní krajinu, města, kulturní památky, muzea, galerie, programově zaměřená centra i kulturní události.

\section{Produkt kulturního cestovního ruchu}

$\mathrm{Z}$ marketingového pohledu rozumíme produktem cokoliv, co slouží k uspokojování potřeb zákazníků (hmotné výrobky, služby, myšlenky apod.). Produkt cestovního ruchu pak musí uspokojovat potřeby účastníků cestovního ruchu, přičemž se téměř výhradně jedná o určitý komplex služeb, který je prodáván pod společným názvem. Jejich spotřebou vzniká zážitek z návštěvy destinace. Charakteristickými rysy produktu cestovního ruchu je prolínání 
hmotných (hotely, restaurace, lázně apod.) a nehmotných (atmosféra, služby) složek. Produkt cestovního ruchu je nehmotný, neskladovatelný a neoddělitelný od osoby poskytovatele. ${ }^{1}$

V oblasti cestovního ruchu nejsou zákazníkům, resp. turistům či návštěvníkům nabízeny ani tak hmotné produkty, jako spíše služby. A pro oblast kulturního cestovního ruchu je to víc než typické. Vždyt' návštěvníkům památky není $\mathrm{v}$ rámci vstupného prodávána samotná památka, ale pouze možnost navštívit určité prostranství, prostory či interiéry a zhlédnout jejich vybavení např. v rámci zvolené prohlídkové trasy. Už samotná př́ítomnost v takovémto jedinečném prostředí a možnost prohlédnout si zajímavé expozice je pro návštěvníky zážitkem. Pro kulturní turisty je tedy návštěva památek atraktivní po mnoha stránkách. A aby mohla být ona nehmatatelná atraktivita a výjimečnost památky turistům vůbec nabídnuta a prodána, musí být transformována do něčeho, co mohou návštěvníci spotřebovat, využít, a co jim přináší užitek. Tím je právě produkt kulturního cestovního ruchu. A přestože jej nazýváme produktem, př́nos pro zákazníka je spíše nehmatatelný, je spojen s duševním prožitkem a měl by vyvolávat pozitivní emoce.

Typickým produktem kulturních destinací jsou zejména prohlídky interiérů, expozic a výstav památkových objektů, muzeí a galerií, návštěvy kulturně-vzdělávacích programů, divadelních představení, koncertů, festivalů, historických akcí atd. Produkt kulturního cestovního ruchu nemůžeme ztotožnit s atraktivitou; vzniká transformací kulturního potenciálu do něčeho, co může turista využít. Produktem může být ale i samotné prostředí kulturní destinace, které je natolik atraktivní, že přitahuje zájem turistů a z toho důvodu je zahrnuto do prohlídkové trasy. Výše zmíněné atraktivity tvoří základ produktu kulturního cestovního ruchu. Součástí produktu jsou také doplňkové a doprovodné služby, jako např. prodej suvenýrů, publikací, řemeslných výrobků apod. Produktem kulturního cestovního ruchu může být také fyzické prostředí např. zrríceniny hradu s atraktivními výhledy do krajiny jako součást prohlídkové trasy.

Samotná kvalita a hodnota sbírek a programů, které tvoří podstatu produktu, nezajistí vždy potřebnou poptávku. Návštěvníka často zajímá přidaná hodnota, tedy služby a kontext, v nichž je jádro nabídky prezentováno. Přitažlivé expozice, kvalitně připravené programy, kulturní, tematické aj. akce podpořené stejně kvalitními doprovodnými službami a pečlivou propagací jsou zárukou úspěchu a zájmu návštěvníků. Kulturní destinace proto musí co nejkvalitnější základní produkt doplnit stejně kvalitním rozšířeným produktem, a sice komplexem doplňkových služeb (stravovací služby, prodej apod.) (Kesner a kol. 2008, s. $73-75)$.

\section{Možnosti dynamizace produktu kulturního cestovního ruchu}

V současnosti hrají stále větší roli v cestovním ruchu produkty ve formě nejrůznějších událostí, tedy organizovaných akcí. V literatuře se pak často setkáváme s označením „event tourism“, nebot' účastníci cestovního ruchu nejsou motivováni k cestování do jiných destinací už jen statickými památkami a atraktivitami cestovního ruchu, ale znovu se potvrzuje to, že lidé čím dál více cestují za účelem prožití atraktivních zážitků. Dnešní společnost totiž považuje zážitky a jejich sdílení s ostatními za určité vyjádření svého společenského statusu.

\footnotetext{
${ }^{1}$ CZECHTOURISM. Manuál produktů v cestovním ruchu [online]. Praha: CzechTourism [vid. 14. listopadu 2015]. Dostupné z:

<http://issuu.com/dringconsulting/docs/manual_produktu_v_cestovnim_ruchu?e=7125351/1306965>.
} 
Kotíková a Schwartzhoffová (2008, s. 10) uvádějí v této souvislosti definici autora Getze, který chápe event tourism jako systematické plánování a rozvoj faktorů, které budují image atraktivit a destinací, přičemž dotčeným segmentem na trhu cestovního ruchu jsou takoví účastníci cestovního ruchu, kteří cestují, aby navštívili určitou událost, nebo kteří jsou motivováni $\mathrm{k}$ návštěvě určité události mimo domov.

V souvislosti s přípravou kulturních produktů v podobě organizovaných akcí nelze nezmínit také pojem kreativní průmysl nebo kreativní cestovní ruch. Stále významnější roli v cestovním ruchu hrají totiž i prvky tzv. nehmotné kultury, tedy např. atmosféra místa, pouliční kultura, zvyky a tradice, nejrůznější etnika a jejich způsob života atd. I to kulturní destinace berou v potaz, snaží se je rozvíjet a zahrnovat do svých kulturních produktů. Zákazníci nechtějí jen pasivně konzumovat nabízené produkty, ale chtějí se stát jejich součástí. Kreativní cestovní ruch tedy může být definován jako cestovní ruch, který nabízí návštěvníkům př́iležitost rozvíjet vlastní kreativní potenciál prostřednictvím aktivní účasti na zážitcích, kterými se zároveň učí a které jsou typické pro destinaci, v níž jsou realizovány (Richards a Raymond In Richards 2001, s. 65). Kreativní cestovní ruch spočívá v poznání a objevování sebe sama, i celého světa, avšak spíše než předpřipravené zážitky nabízené turistickým průmyslem ponechává každému svobodu v tom, jak jej bude objevovat.

Řada autorů považuje události v cestovním ruchu za prostředky, které dynamizují nabídku cestovního ruchu určité destinace, města, místa (např. Gúčik 2011, nebo Pompurová 2014). Gúčik (2011) uvádí, že kulturní, obchodní a sportovní akce jsou dynamickým prvkem, který vyvolává rozvoj cestovního ruchu. Produkty cestovního ruchu můžeme tedy z tohoto hlediska rozlišit na tzv. statické, které přitahují návštěvnost už jen svou vlastní existencí. Jejich atraktivita je dána historicky a přirozeně, jedná se o historická města, místa, archeologické lokality, kulturně historické památky, muzea aj., jež jsou natolik cenné a atraktivní, že pouhá prohlídka (účast na prohlídkové trase) je pro návštěvníky přitažlivým zážitkem. Na druhé straně jsou produkty dynamické (hudební či folklorní festivaly, divadelní představní, historické jarmarky, šermířské souboje, ale i sportovní události apod.), které naopak přitahují pozornost návštěvníků tím, že umožní odnést si zážitek právě vlastní účastí na tomto typu produktu cestovního ruchu. Obsahuje-li nabídka cestovního ruchu dynamické produkty, stává se $\mathrm{z}$ tohoto úhlu pohledu dynamickou.

Organizované akce neboli eventy v cestovním ruchu, lze klasifikovat z různých hledisek; nejvýznamnějším je tematické členění, dále pak např. hledisko počtu a typu účastníkủ, místa konání, doby trvání, periodicity apod.

Tematické členění eventů v souladu se specifiky cestovního ruchu České republiky uspořádaly Kotíková a Schwartzhoffová (2008) následujícím způsobem:

1) kulturní eventy (hudební, filmové, divadelní festivaly, koncerty muzikály, výstavy a ostatní kulturní akce),

2) sportovní eventy (olympiáda, mistrovství světa, individuální sportovní utkání, maratonský běh, rekreační sporty apod.),

3) eventy vycházející z místních zvyků a tradic (folklorní akce, přehlídky, místní tradice, rekonstrukce historických událostí, bitev aj., historická přestavení, gastronomické akce, akce spojené s legendární postavou, mýtem nebo událostí atd.),

4) zábavné a společenské eventy (oslavy Silvestra, dětské dny, plesy, tematické parky a volnočasová centra atd.),

5) náboženské eventy (církevní svátky a události, poutě, návštěvy významných církevních prrestavitelů, setkání věrících atd.), 
6) specifické eventy v cestovním ruchu (kongresy, konference, incentivní akce, veletrhy, výstavy, presstripy, famtripy, street show atd.),

7) ostatní eventy (svatby, politické eventy, firemní eventy aj).

Zmíněné organizované akce (snad kromě tzv. soukromých eventů jako jsou svatby, rodinné oslavy apod.), mají pro cestovní ruch velký význam. Pro dynamizaci nabídky kulturního cestovního ruchu jsou podstatné zejména kulturní, náboženské, společenské eventy a eventy vycházející z místních tradic, ale i eventy zaměřené na tzv. MICE ${ }^{2}$ klientelu - dle potenciálu konkrétního města či destinace.

\section{Kulturní události v České republice}

Česká republika disponuje značným množství tzv. kulturních destinací, ovšem jednotlivé kraje ČR mají v této oblasti různorodý potenciál. Počet jednotlivých kulturních destinací ČR shrnuje tabulka v následující podkapitole. Při bližší analýze se zaměříme na dva vybrané regiony, a to na Moravskoslezský a Olomoucký kraj s důrazem na počet a návštěvnost eventů.

\subsection{Kulturní potenciál České republiky}

Tabulka 1 zachycuje počty jednotlivých kulturních destinací (kulturních zařízení a akcí) v České republice.

Tabulka 1: Počet kulturních destinací v jednotlivých krajích ČR v roce 2014

\begin{tabular}{|c|c|c|c|c|}
\hline \multirow{2}{*}{ Kraj } & \multicolumn{4}{|c|}{ Kulturní destinace } \\
\hline & Památkové objekty & Muzea, galerie & Kulturní události & Výstavy \\
\hline HI. město Praha & 18 & 95 & 829 & 940 \\
\hline Středočeský & 50 & 123 & 1797 & 160 \\
\hline Jihočeský & 36 & 60 & 713 & 163 \\
\hline Plzeňský & $21 *$ & 53 & $873 *$ & 89 \\
\hline Karlovarský & $8 *$ & 24 & $41 *$ & 71 \\
\hline Ústecký & $34 *$ & 45 & 1255 & 117 \\
\hline Liberecký & $14 *$ & 41 & $307 *$ & 57 \\
\hline Královéhradecký & 22 & 79 & $742 *$ & 60 \\
\hline Pardubický & $12 *$ & 50 & $291 *$ & 73 \\
\hline Vysočina & $17 *$ & 48 & $226^{*}$ & 78 \\
\hline Jihomoravský & $26^{*}$ & 80 & $1792 *$ & 221 \\
\hline Olomoucký & $11 *$ & 31 & $3210 *$ & 94 \\
\hline Zlínský & $10 *$ & 48 & $171 *$ & 126 \\
\hline Moravskoslezský & 12 & 64 & 373 & 255 \\
\hline ČR celkem & 308 & 841 & 12905 & 2504 \\
\hline
\end{tabular}

Zdroj: vlastní zpracování dle: NIPOS, 2015. Základní statistické údaje o kultuře v České republice 2014. I. díl. Kulturni dédictví. Muzea, galerie a památkové objekty. Praha: NIPOS. 40 s. ISBN 978-80-7068-293-7; NIPOS, 2015. Základní statistické údaje o kultuře v České republice 2014. II. díl. Umění. Divadla, hudební soubory, výstavní činnost a festivaly. Praha: NIPOS. 102 s. ISBN 978-80-7068-294-4.

\footnotetext{
2 MICE je zkratka tvořena počátečními písmeny anglických slov Meetings (setkání, schůze), Incentives (incentivní - motivační pobyty za odměnu), Conferences/Conventions (konference, kongresy) a Events/Exhibitions (organizované akce, výstavy, veletrhy) a je spojována zejména s kongresovým cestovním ruchem.
} 
Památkovými objekty rozumíme hrady, zámky, kostely, kláštery, věže, zříceniny, mlýny apod., jež jsou návštěvníkům zpř́stupněny za vstupné a které jsou ve správě Národního památkového ústavu, měst a obcí, církví, soukromých subjektů, nadací, sdružení apod. Nejsou mezi ně zahrnuty ty památkové objekty, jež jsou spravovány muzei a galeriemi. K počtu muzeí a galerií jsou zahrnuty i jejich pobočky a památníky (objekty, v nichž jsou instalovány expozice či výstavy) a ve statistických údajích jsou zahrnuty jen ty galerie, které vlastní sbírkové předměty, ne však galerie prodejní. Kulturními událostmi míníme ty kulturní akce, které byly zorganizovány památkovými objekty. Jedná se napřr. o výstavy, koncerty, dramatická vystoupení, akce lidové kultury apod. Výstavy profesionálního výtvarného umění a architektury mohou být pořádány $\mathrm{v}$ galeriích, výstavních síních nebo jiných prostorách k tomu určených, avšak samy nevlastní sbírkové předměty.

Údaj, který je v Tabulce 1 doplněn hvězdičkou (*) je neúplný, nebot' data o počtu kulturních destinací za rok 2014 byla čerpána ze statistik Ministerstva kultury (NIPOS), v nichž však ne všechny instituce souhlasí se zveřejněním statistických údajů. Celkové počty jednotlivých kulturních destinací (ř́adek „ČR celkem“) však obsahují údaje za všechna šetřená zařízení (včetně těch, které své údaje nechtějí zveřejňovat). Matematický součet položek ve sloupci „Památkové objekty“ a „Kulturní události“ tedy neodpovídá uvedeným celkovým hodnotám. Instituce, které nezveřejnily statistická data o své činnosti, patřily do kategorie ,památkové objekty zrrizované podnikatelskými subjekty a podnikateli“. Lze tedy předpokládat, že tyto instituce tak učinily zejm. $\mathrm{z}$ toho důvodu, že ve své kategorii jsou v daném kraji jediné a jejich údaje by se tak staly individuálními.

Z Tabulky 1 je však i přesto zřejmé, že počet kulturních zařízení je v jednotlivých krajích značně odlišný a různorodý. Tradiční kulturní destinací je Hlavní město Praha, bohatou kulturní nabídku má však i Středočeský nebo Jihomoravský kraj. Moravskoslezský kraj sice počtem zpř́stupněných památek a muzeí i počtem kulturních akcí nedosahuje ani prủměru České republiky, avšak na jeho území se v roce 2014 uspořádal druhý nejvyšší počet výstav profesionálního umění a architektury. Olomoucký kraj naopak vyniká počtem organizovaných kulturních událostí - v roce 2014 jich uspořádal v porovnání s ostatními kraji nejvíce.

\subsection{Poptávka po kultuře ve vybraných regionech}

Následující grafy znázorňují návštěvnost kulturních destinací v období let 2008 až 2014. Sledován je vývoj návštěvnosti těchto kulturních destinací jednak za celou Českou republiku, a jednak v Moravskoslezském a Olomouckém kraji.

Obrázek 1: Návštěvnost kulturních destinací ČR mezi lety 2008 - 2014 (v tis. osob)

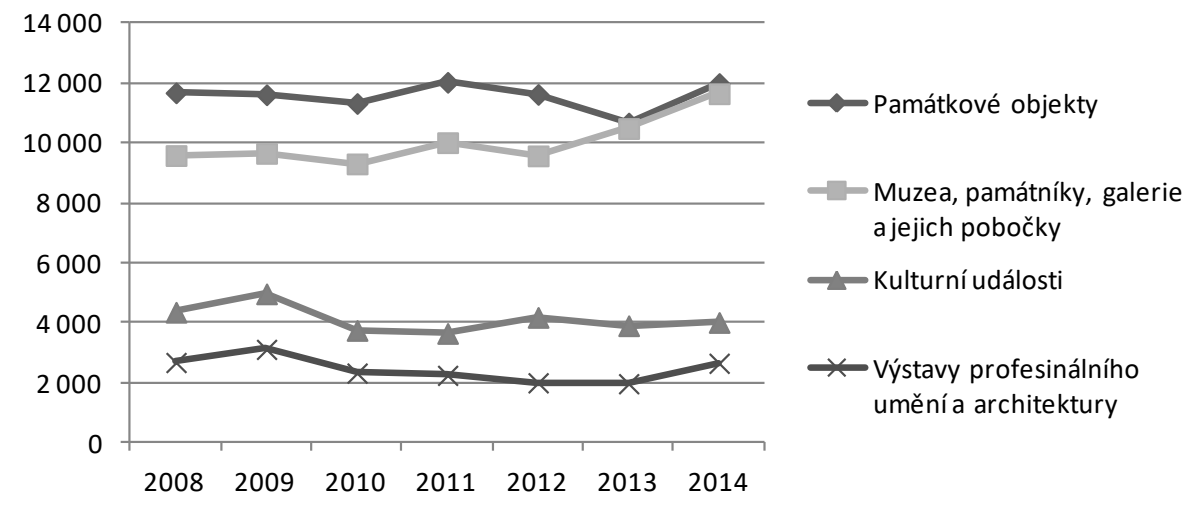

Zdroj: vlastní zpracování dle: Český statistický úřad. Kulturní zařizení v ČR 2013 [online]. Praha: ČSÚ, zveřejněno: 2. 9. 2014, aktualizováno: 26. 10. 2015 [vid. 14. listopadu 2015]. Dostupné z: <https://www.czso.cz/csu/czso/kulturni-zarizeni-v-cr-2013-3aild6g7ga>. NIPOS, 2015. Základni statistické 
údaje o kultuře v České republice 2014. I. díl. Kulturni dédictví. Muzea, galerie a památkové objekty. Praha: NIPOS. 40 s. ISBN 978-80-7068-293-7. NIPOS, 2015. Základni statistické údaje o kultuře v České republice 2014. II. díl. Uméní. Divadla, hudební soubory, výstavní činnost a festivaly. Praha: NIPOS. 102 s. ISBN 978-807068-294-4.

Jak je z Obrázku 1 zřejmé, návštěvnost jednotlivých kategorií kulturních destinací České republiky se vyvíjí podobným, v posledních letech mírně rostoucím trendem. Pouze u muzeí a galerií je patrný výraznější růst návštěvnosti. Nejnavštěvovanější jsou v České republice tradičně památkové objekty a dále právě muzea a galerie. Značně nižší návštěvnost mají kulturní události a výstavy profesionálního umění a architektury, přičemž návštěvnost těchto akcí je výrazněji závislá na počtu těchto událostí.

Z Obrázku 2 je pak patrné, že vývoj návštěvnosti kulturních destinací Moravskoslezského a Olomouckého kraje nekoresponduje s celorepublikovým vývojem.

Obrázek 2: Návštěvnost kulturních destinací Moravskoslezského a Olomouckého kraje mezi lety $2008-2014$ (v tis. osob)
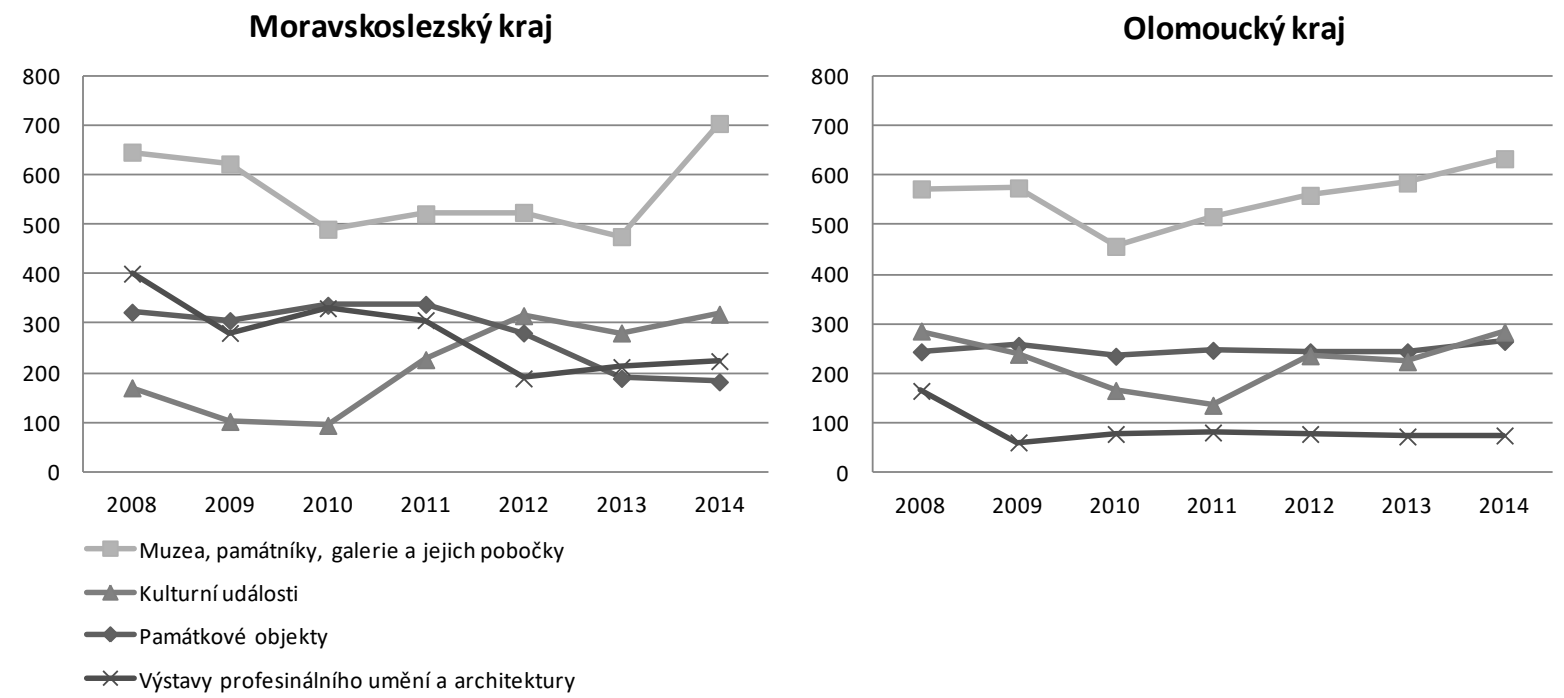

Zdroj: vlastní zpracování dle Český statistický úřad. Kulturní zařizení v ČR 2013 [online]. Praha: ČSÚ, zveřejněno: 2. 9. 2014, aktualizováno: 26. 10. 2015 [vid. 14. listopadu 2015]. Dostupné z: <https://www.czso.cz/csu/czso/kulturni-zarizeni-v-cr-2013-3aild6g7ga〉. NIPOS, 2015. Základní statistické údaje o kultuře v České republice 2014. I. díl. Kulturni dédictví. Muzea, galerie a památkové objekty. Praha: NIPOS. 40 s. ISBN 978-80-7068-293-7. NIPOS, 2015. Základní statistické údaje o kultuře v České republice 2014. II. dil. Umění. Divadla, hudebni soubory, výstavní činnost a festivaly. Praha: NIPOS. 102 s. ISBN 978-807068-294-4

Na rozdíl od jiných krajů, v Moravskoslezském kraji převyšuje návštěvnost muzeí a galerií nad návštěvností památek. Je to logicky dáno tím, že počet památkových objektů je v kraji výrazně nižší, než počet muzeí, galerií a jejich poboček. Některé hojně navštěvované hrady a zámky v regionu jsou evidovány jako pobočky muzeí, čímž tedy zkreslují statistiky v oblasti návštěvnosti muzeí a galerií. Celorepublikově návštěvnost muzeí a galerií roste, což se od roku 2014 projevuje i v Moravskoslezském kraji. Na rozdíl od vývoje v celé České republice roste v Moravskoslezském kraji výrazněji návštěvnost kulturních akcí, která v posledních letech převyšuje jak návštěvnost památkových objektů, tak výstav profesionálního umění.

Stejně jako v Moravskoslezském kraji, i kraji Olomouckém jsou nejnavštěvovanější kulturními destinacemi muzea a galerie. Jejich návštěvnost však oproti Moravskoslezskému kraji roste kontinuálně od roku 2011. V letech 2010 a 2011 se totiž v návštěvnosti kulturních 
destinací projevily důsledky tzv. finanční krize, a to nejen ve zkoumaných regionech, ale i v celé České republice. Kulturně historické památky v Olomouckém kraji si udržují dlouhodobě konstantní návštěvnost pohybující se okolo 240 tis. návštěvníků ročně. Rozkolísaně se však v Olomouckém kraji vyvíjí návštěvnost kulturních akcí. Počet návštěvníků tzv. profesionálních výstav zůstává konstantní, celkově je však nižšś než v kraji Moravskoslezském, nebot' i těchto akcí se na Olomoucku organizuje podstatně méně.

\section{Analýza vztahu počtu kulturních akcí a počtu jejich návštěvníků}

$\mathrm{Na}$ následujících řádcích budeme analyzovat prvky dynamizující nabídku cestovního ruchu kulturní události, přičemž vyjdeme z předpokladu, že s růstem počtu kulturních akcí v kraji roste i počet jejich návštěvníků. Stanovíme tedy Hypotézu 1: Mezi počtem kulturních akcí organizovaných v Moravskoslezském kraji a počtem jejich návštěvníků existuje pozitivní statistický vztah.

Hypotézu ověříme pomocí korelační analýzy počtu a návštěvnosti kulturních akcí pořádaných v Moravskoslezském kraji v letech 2008 až 2014. Vstupní data pro analýzu obsahuje Tabulka 2.

Tabulka 2: Počet kulturních událostí a jejich návštěvnost v Moravskoslezském kraji

\begin{tabular}{|c|r|r|}
\hline Rok & $\begin{array}{c}\text { Počet kulturních } \\
\text { událostí }\end{array}$ & $\begin{array}{c}\text { Počet návštěvníků } \\
\text { v tis. osob }\end{array}$ \\
\hline $\mathbf{2 0 0 8}$ & 219 & 170 \\
\hline $\mathbf{2 0 0 9}$ & 205 & 102 \\
\hline $\mathbf{2 0 1 0}$ & 176 & 94 \\
\hline $\mathbf{2 0 1 1}$ & 300 & 227 \\
\hline $\mathbf{2 0 1 2}$ & 369 & 316 \\
\hline $\mathbf{2 0 1 3}$ & 357 & 281 \\
\hline $\mathbf{2 0 1 4}$ & 373 & 319 \\
\hline
\end{tabular}

Zdroj: vlastní zpracování dle Český statistický úřad. Kulturní zařizení v ČR 2013 [online]. Praha: ČSÚ, zveřejněno: 2. 9. 2014, aktualizováno: 26. 10. 2015 [vid. 14. listopadu 2015]. Dostupné z: <https://www.czso.cz/csu/czso/kulturni-zarizeni-v-cr-2013-3aild6g7ga>. NIPOS, 2015. Základni statistické údaje o kultuře v České republice 2014. I. díl. Kulturní dědictví. Muzea, galerie a památkové objekty. Praha: NIPOS. 40 s. ISBN 978-80-7068-293-7. NIPOS, 2015. Základni statistické údaje o kultuře v České republice 2014. II. díl. Umění. Divadla, hudební soubory, výstavní činnost a festivaly. Praha: NIPOS. 102 s. ISBN 978-807068-294-4

V rámci korelační analýzy, která se používá pro vysvětlení závislosti mezi daty, nás zajímá hodnota tzv. korelačního koeficientu, resp. jeho bodového odhadu $(r)$, jenž měři těsnost závislosti proměnných a nabývá hodnot $[-1 ; 1]$. Jestliže se s růstem hodnot jedné proměnné zvyšují hodnoty i druhé proměnné, jedná se o př́mou lineární závislost, korelační koeficient dosahuje kladných hodnot a blíží se k 1. Naopak, klesají-li s růstem hodnot jedné proměnné hodnoty druhé proměnné, korelační koeficient se blíží -1. Dosáhne-li korelační koeficient hodnoty 0 , neexistuje mezi proměnnými lineární závislost.

Pro výpočet korelačního koeficientu lze využít např. aplikaci MS Excel a její funkci Correl, či nástroj pro analýzu dat Korelace. Pokud podrobíme korelační analýze data o počtu kulturních událostí a jejich návštěvnosti v Moravskoslezském kraji, pak zjistíme, že korelační koeficient dosáhne hodnoty 0,98 . Můžeme tedy říci, že byla potvrzena statistická závislost mezi počtem kulturních akcí v Moravskoslezském kraji a počtem jejich návštěvníků 
Ne vždy přináší hodnota korelačního koeficientu jednoznačné výsledky, proto je vhodné závislost mezi proměnnými prověřit testem statistické významnosti korelačního koeficientu:

1. $H_{0}: \rho=0$.

$H_{1}: \rho \neq 0$.

2. Testové kritérium: $T=\frac{r}{\sqrt{1-r^{2}}} \sqrt{n-2} ;$ kde $n$ je počet dvojic $x_{i}$ a $y_{i}$.

3. Kritická hodnota Studentova rozdělení: $t_{(n-2)}(\alpha)$.

4. Na hladině významnosti $\alpha$ testujeme závislost mezi proměnnými. Pokud testové kritérium spadá do kritického oboru $\left(T>t_{(n-2)}(\alpha)\right)$, pak zamítáme nulovou hypotézu a přijímáme hypotézu alternativní.

Testové kritérium pro námi analyzovaná data je 12,52 a je tedy větší než kritická hodnota 2,57 (na hladině významnosti $\alpha=0,05$ ). S $95 \%$ pravděpodobností je tedy mezi zkoumanými proměnnými pozitivní statistická lineární závislost.

Pokud budeme zkoumat vztah mezi počtem kulturních akcí Olomouckého kraje a jejich návštěvností, a stanovíme tedy Hypotézu 2: Mezi počtem kulturních akcí organizovaných v Olomouckém kraji a počtem jejich návštěvníků existuje pozitivní statistická závislost, pak zjistíme značně rozdílné výsledky než u kraje Moravskoslezského (vstupní údaje jsou obsaženy v Tabulce 3).

Tabulka 3: Počet kulturních událostí a jejich návštěvnost v Olomouckém kraji

\begin{tabular}{|c|r|r|}
\hline Rok & $\begin{array}{c}\text { Počet kulturních } \\
\text { událostí }\end{array}$ & $\begin{array}{c}\text { Počet návštěvníků } \\
\text { v tis. osob }\end{array}$ \\
\hline 2008 & 3934 & 286 \\
\hline 2009 & 1825 & 239 \\
\hline 2010 & 3064 & 166 \\
\hline 2011 & 2940 & 136 \\
\hline 2012 & 2643 & 236 \\
\hline 2013 & 2322 & 224 \\
\hline 2014 & 3210 & 284 \\
\hline
\end{tabular}

Zdroj: vlastní zpracování dle Český statistický úřad. Kulturní zařizení v ČR 2013 [online]. Praha: ČSÚ, zveřejněno: 2. 9. 2014, aktualizováno: 26. 10. 2015 [vid. 14. listopadu 2015]. Dostupné z: <https://www.czso.cz/csu/czso/kulturni-zarizeni-v-cr-2013-3aild6g7ga>. NIPOS, 2015. Základni statistické údaje o kultuře v České republice 2014. I. díl. Kulturní dédictví. Muzea, galerie a památkové objekty. Praha: NIPOS. 40 s. ISBN 978-80-7068-293-7. NIPOS, 2015. Základní statistické údaje o kultuře v České republice 2014. II. díl. Umění. Divadla, hudebni soubory, výstavní činnost a festivaly. Praha: NIPOS. 102 s. ISBN 978-807068-294-4

Korelační koeficient dosáhnul hodnoty 0,22 , mezi proměnnými neexistuje téměř žádný vztah. Stejně tak test statistické významnosti korelačního koeficientu doložil, že platí nulová hypotéza o nekorelovanosti proměnných; testové kritérium $(0,51)$ spadá do tzv. oboru přijetí, nebot' kritická hodnota je 2,57. Přijímáme nulovou hypotézu. Statistická závislost mezi počtem kulturních akcí konaných v Olomouckém kraji a počtem jejich návštěvníkủ nebyla potvrzena. 


\section{Výsledky a diskuse}

Výsledky výše provedených analýz shrnuje Tabulka 4.

Tabulka 4: Vyhodnocení hypotéz

\begin{tabular}{|c|r|r|r|c|}
\hline Hypotéza & Korelační koeficient & Testové kritérium & Kritická hodnota & Závěr \\
\hline 1 & 0,9844 & 12,5193 & 2,5706 & existuje závislost \\
\hline 2 & 0,2227 & 0,5108 & 2,5706 & neexistuje závislost \\
\hline
\end{tabular}

Zdroj: vlastní zpracování

Výsledky analýzy potvrdily Hypotézu 1, která předpokládala pozitivní statistickou závislost mezi počtem pořádaných kulturních akcí v Moravskoslezském kraji a počtem jejich návštěvníků. Můžeme tedy říci, že návštěvnost kulturních událostí v Moravskoslezském kraji se zvyšuje s růstem počtu těchto akcí.

Hypotéza 2, která se domnívala, že stejný vztah mezi počtem kulturních akcí a počtem jejich návštěvníků platí i v kraji Olomouckém, však byla vyvrácena. Nemůžeme tedy tvrdit, že s růstem počtu kulturních akcí v Olomouckém kraji, roste i počet návštěvníků.

Vykrystalizovaly tak dva př́klady krajů, v nichž se projevují opačné tendence v návštěvnosti kulturních akcí. Z výsledku analýzy je tedy patrné, že v Moravskoslezském kraji můžeme považovat kulturní akce za nevyužitý potenciál. Zájem návštěvníků o kulturní akce v kraji je značný a zvyšuje se s tím, jak roste nabídka těchto akcí, což by mělo být pozitivním signálem pro organizátory těchto akcí.

Na druhé straně, Olomoucký kraj je trhem, který je kulturními akcemi nasycený a př́íprava dalších kulturních akcí jejich návštěvnost již nezvýší. V kraji by tedy mělo dojít spíše $\mathrm{k}$ jejich konsolidaci.

\section{Závěr}

Výsledky analýz ukázaly, že zájem návštěvníků o kulturní akce, považované za produkty dynamizující nabídku cestovního ruchu, se v Moravskoslezském a Olomouckém kraji liší. Ačkoliv Olomoucký kraj dlouhodobě každoročně pořádá mnohem více kulturních událostí než kraj Moravskoslezský, počet návštěvníků těchto akcí dosahuje v posledních letech v obou krajích podobných hodnot. Vzhledem k dosavadnímu vývoji lze říci, že zvýšení počtu organizovaných kulturních akcí v Moravskoslezském kraji zajistí i růst počtu návštěvníků těchto akcí. Organizátoři kulturních akcí v Moravskoslezském kraji by tedy tuto skutečnost měli využít pro podporu návštěvnosti kraje. S návštěvníky totiž do regionu přicházejí $\mathrm{i}$ další dodatečné př́ijmy nejen pro oblast cestovního ruchu.

V Olomouckém kraji podobný vývoj jako v kraji Moravskoslezském očekávat nelze. Můžeme tedy ř́́ci, že ačkoli kraj disponuje bohatým kulturním programem, možnosti kulturního publika jsou omezené. Kulturní publikum je totiž specifickým typem návštěvníků, kteří mají vztah ke kultuře a umění, mají dostatek času a chuti se návštěvnám kulturních akcí věnovat a chtějí si odnést určitý kulturní zážitek. Většinou jsou to lidé vzdělanější, s vyššími příjmy, mírně mezi nimi převažují ženy nad muži a často už v dětství byli ke kultuře vedeni, přičemž v dospělosti se k ní znovu vracejí. Na druhé straně existuje skupina tzv. nenávštěvníků, tedy osob, které se $\mathrm{z}$ nejrůznějších důvodů kultury neúčastní. Nejčastějšími tzv. bariérami účasti na kultuře jsou dle Kesnera (2005, s. 102 - 111) disponibilní časový fond, informovanost, kulturní kompetence a vlastní vnímání image kulturní destinace. Pro organizátory kulturních akcí je tedy důležité znát nejen své návštěvníky, ale vědět také, kdo jsou jejich nenávštěvníci 
a snažit se připravit takové produkty, resp. přizpůsobit celou strategii, marketingové aktivity atd. tak, aby bylo možné bariéry návštěvnosti překonat.

Přes výše uvedené je však nutno říci, že zájem turistů o účast na kulturních akcích je v destinaci Česká republika dlouhodobě konstantní (dle výše zmíněných statistik ČSÚ a NIPOSu či výsledků primárního výzkumu domácího cestovního ruchu ${ }^{3}$ agentury CzechTourism). Kulturní události jsou tedy příležitostí, které je třeba využít pro rozvoj cestovního ruchu. Cestovatelé totiž touží po zážitcích z návštěvy nového místa, města, kraje. Lze tedy říci, že lidé jsou výrazně motivováni k cestování nejrůznějšími kulturními důvody. Jedním z nich je poznávání navštíveného místa i prostřednictvím kulturních akcí. Tento fakt je výzvou pro aktéry v oblasti cestovního ruchu snažit se lépe a kvalitněji tyto potřeby turistů uspokojovat.

\section{Literatura}

[1] CZECHTOURISM. Manuál produktů v cestovním ruchu [online]. Praha: CzechTourism [vid. 14. listopadu 2015]. Dostupné $\mathrm{z}$ : issuu.com/dringconsulting/docs/ manual_produktu_v_cestovnim_ruchu?e=7125351/1306965

[2] Český statistický úřad. Kulturní zařizení v ČR 2013 [online]. Praha: ČSÚ. zveřejněno: 2. 9. 2014, aktualizováno: 26. 10. 2015 [vid. 14. listopadu 2015]. Dostupné z: www.czso.cz/csu/czso/kulturni-zarizeni-v-cr-2013-3aild6g7ga.

[3] GÚČIK, M. a kol., 2011. Cestovný ruch. Politika a ekonómia. Banská Bystrica: SlovakSwiss Tourism. ISBN 80-89090-98-3.

[4] INDROVÁ, J. a kol., 2007. Cestovní ruch (základy). Praha: Oeconomica. ISBN 978-80245-1252-5.

[5] KESNER, L., 2015. Marketing a management muzeí a památek. Praha: Grada. ISBN 80247-1104-4.

[6] KESNER, L. a kol., 2008. Management kulturního cestovního ruchu. Praha: Ministerstvo pro místní rozvoj ČR.

[7] KMECO, L., 2006. Využitie kultúrneho dedičstva v cestovnom ruchu. Rukovät' $k$ predmetu Dejiny kultúry. Banská Bystrica: Univerzita Mateja Bela. ISBN 80-8083-245-5

[8] KOTÍKOVÁ, H. a E. SCHWARTZHOFFOVÁ, 2008. Nové trendy v pořádání akcí a událostí (events) v cestovním ruchu. Praha: Ministerstvo pro místní rozvoj ČR. ISBN 978-80-87147-05-4.

[9] JAKUBÍKOVÁ, D., 2012. Marketing v cestovním ruchu. 2. vyd. Praha: Grada. ISBN 978-80-247-3247-3.

[10] POMPUROVÁ, M., 2014. Motivácia účasti na organizovaných podujatiach v cestovnom ruchu. In: 3. Mezinárodní vědecká konference Cestovní ruch, hotelnictví a lázeňství ve světle vědeckého výzkumu a praxe. Karviná: SU OPF, s. 302-309. ISBN 978-80-7248955-8.

[11] RICHARDS, G., 2001. The development of cultural tourism in Europe. In: G. RICHARDS, ed. Cultural attractions and European Tourism. Wallingford: CABI, p. 329. ISBN 0-85199-440-7.

\footnotetext{
${ }^{3}$ Výzkum zaměrený na domácí cestovní ruch [online]. (C) CzechTourism, 2010, (C Ipsos, 2010 [vid. 2. února 2016]. Dostupné z: 〈http://monitoring.czechtourism.cz/>.
} 
[12] UNWTO, 2001. Tourism 2020 Vision: Volume 7: Global Forecast and Profiles of Market Segments [online]. Madrid: UNWTO [vid. 7. července 2016]. ISBN 92-8440466-5. Dostupné z: www.sete.gr/files/Media/Ebook/110303_Global\%20Forecasts\% 20and\%20Profiles\%20of\%20Market\%20Segments.pdf

[13] Výzkum zaměrený na domácí cestovní ruch [online]. (C) CzechTourism, 2010, (C) Ipsos, 2010 [vid. 2. února 2016]. Dostupné z: monitoring.czechtourism.cz 